\title{
Periodontal Condition in High-Risk Pregnant Women
}

Condição Periodontal em Gestantes de Alto Risco

\section{Condición Periodontal en Mujeres Embarazadas de Alto Riesgo}

Suzely Adas Saliba MOIMAZ Department of Preventive and Restorative Dentistry, São Paulo State University (UNESP), School of Dentistry, 16015-050 Araçatuba - SP, Brazil https://orcid.org/0000-0002-4949-529X

Fernando Yamamoto CHIBA

Department of Preventive and Restorative Dentistry, São Paulo State University (UNESP), School of Dentistry, 16015-050 Araçatuba - SP, Brazil https://orcid.org/0000-0003-4406-405X

Fernanda Izaura RODRIGUES

Department of Preventive and Restorative Dentistry, São Paulo State University (UNESP), School of Dentistry, 16015-050 Araçatuba - SP, Brazil

Cléa Adas Saliba GARBIN

Department of Preventive and Restorative Dentistry, São Paulo State University (UNESP), School of Dentistry, 16015-050 Araçatuba - SP, Brazil https://orcid.org/0000-0001-5069-8812

Orlando SALIBA

Department of Preventive and Restorative Dentistry, São Paulo State University (UNESP), School of Dentistry, 16015-050 Araçatuba - SP, Brazil https://orcid.org/0000-0003-1439-4197

Nemre Adas SALIBA

Department of Preventive and Restorative Dentistry, São Paulo State University (UNESP), School of Dentistry, 16015-050 Araçatuba - SP, Brazil https://orcid.org/0000-0001-9608-1631

\section{Abstract}

Introduction: Oral health is related to the systemic health of the pregnant woman and the fetus, highlighting the importance of the oral health approach as a gestational health problem. Objective: To verify the prevalence of periodontal pocket and to analyze the relationship of the condition with sociodemographic factors, medical history, and behavioral profile in high-risk pregnant women. Methods: This cross-sectional, observational and analytical study comprised 800 high-risk pregnant women. Interviews were performed using a structured questionnaire to obtain data on sociodemographic characteristics, medical history and behavioral factors and the periodontal examination was carried out using the Community Periodontal Index (CPI). Statistical analyzes were performed to estimate odds ratio $(\mathrm{OR})$ and $95 \%$ confidence interval $(\mathrm{Cl})$ between periodontal pocket and variables age group, living area, skin color, housing, marital status, schooling, family income, gestational period, number of children, arterial hypertension, gestational arterial hypertension, diabetes mellitus, gestational diabetes mellitus, smoking habit and alcoholism. Results: Of the total of 800 pregnant women examined, it was observed that $216(27 \%)$ showed periodontal pocket. The condition was associated with age group (35-45 years: OR=2.498; $\mathrm{Cl}=1.297-4.813 ; \mathrm{p}$-value=0.006), schooling ( $\leq 7$ years: $\mathrm{OR}=1.638 ; \mathrm{Cl}=1.017-2.638 ; \mathrm{p}$-value=0.042), family income ( $\leq \mathrm{USD} \$ 400.00$ : $\mathrm{OR}=1.431 ; \mathrm{Cl}=1.004-2.041 ; \mathrm{p}$-value=0.048), diabetes $(\mathrm{OR}=2.508 ; \mathrm{Cl}=1.511-4.163 ; \mathrm{p}$-value=0.000) and smoking habit $(\mathrm{OR}=2.211$; $\mathrm{Cl}=1.460-3.348 ; \mathrm{p}$-value=0.000). Conclusions: The prevalence of periodontal pocket was high and the factors age, low schooling, low family income, diabetes and smoking habit are related to greater chances of occurrence in high-risk pregnant women.

Descriptors: Pregnancy, High-Risk; Periodontitis; Epidemiology.

\section{Resumo}

Introdução: A saúde bucal está relacionada à saúde sistêmica da gestante e do feto, ressaltando a importância da abordagem da saúde bucal como um problema de saúde gestacional. Objetivo: Verificar a prevalência de bolsa periodontal e analisar a relação da condição com fatores sociodemográficos, história médica e perfil comportamental em gestantes de alto risco. Métodos: Estudo transversal, observacional e analítico com 800 gestantes de alto risco. As entrevistas foram realizadas por meio de questionário estruturado para obtenção de dados sobre características sociodemográficas, histórico mpedico e fatores comportamentais, e 0 exame periodontal por meio do Índice Periodontal Comunitário (IPC). Estimou-se o odds ratio (OR) e o intervalo de confiança de 95\% (IC) para a relação entre bolsa periodontal e as variáveis faixa etária, tipo e área de moradia, cor da pele, estado civil, escolaridade, renda familiar, período gestacional, número de filhos, hipertensão arterial, hipertensão arterial gestacional, diabetes mellitus, diabetes mellitus gestacional, tabagismo e etilismo. Resultados: Do total de 800 gestantes examinadas, observou-se que $216(27 \%)$ apresentavam bolsa periodontal. A condição esteve associada à faixa etária (35-45 anos: $O R=2,498 ; I C=1,297-4,813 ; p$-valor=0,006), escolaridade ( $\leq 7$ anos: $O R=1,638 ; I C=1,017-2,638 ; p$-valor=0,042), renda familiar $(\leq U S D \$ 400,00: \quad O R=1,431 ; \quad I C=1,004-2,041 ; p$-valor=0,048), diabetes (OR=2,508; $I C=1,511-4,163 ; \quad p$-valor=0,000) e tabagismo (OR=2,211; $\quad \mathrm{Cl}=1,460-3,348 ; p$-valor=0,000). Conclusões: A prevalência de bolsa periodontal foi elevada e os fatores idade, baixa escolaridade, baixa renda familiar, diabetes e tabagismo estão relacionados a maiores chances de ocorrência em gestantes de alto risco.

Descritores: Gravidez de Alto Risco; Periodontite; Epidemiologia.

\section{Resumen}

Introducción: La salud bucal se relaciona con la salud sistémica de la gestante y del feto, enfatizando la importancia del abordaje de la salud bucal como problema de salud gestacional. Objetivo: Verificar la prevalencia de bolsa periodontal y analizar la relación de la condición con factores sociodemográficos, antecedentes médicos y perfil conductual en gestantes de alto riesgo. Métodos: Estudio transversal, observacional y analítico con 800 gestantes de alto riesgo. Las entrevistas se realizaron mediante un cuestionario estructurado para obtener datos sobre características sociodemográficas, antecedentes médicos y factores conductuales, y el examen periodontal mediante el Índice Periodontal Comunitario (IPC). Se estimó la odds ratio (OR) y el intervalo de confianza (IC) del 95\% para la relación entre la bolsa periodontal y las variables grupo de edad, tipo y área de residencia, color de piel, estado civil, educación, ingresos familiares, período gestacional, número de hijos, hipertensión arterial, hipertensión arterial gestacional, diabetes mellitus, diabetes mellitus gestacional, tabaquismo y consumo de alcohol. Resultados: Del total de 800 gestantes examinadas, se observó que $216(27 \%)$ presentaban bolsa periodontal. La condición se asoció con la edad (35-45 años: OR=2,488; IC=1,297-4,813 p=0,006), educación ( $\leq 7$ años: $O R=1,638 ; I C=1,017-2,638 ; p=0,042$ ), ingresos familiares ( $\leq$ USD $\$ 400,00$ : OR=1,431; IC=1,004-2,041; $p=0,048$ ), diabetes $(O R=2,508 ; \mathrm{IC}=1,511-4,163 ; p=0,000)$ y tabaquismo $(\mathrm{OR}=2,211 ; \mathrm{IC}=1,460-3,348 ; \mathrm{p}=0,000)$. Conclusiones: La prevalencia de bolsa periodontal fue alta y los factores edad, baja escolaridad, bajos ingresos familiares, diabetes y tabaquismo se relacionan con mayores probabilidades de ocurrencia en gestantes de alto riesgo.

Descriptores: Embarazo de Alto Riesgo; Periodontitis; Epidemiología.

\section{INTRODUCTION}

The prevention of oral diseases during pregnancy has been receiving special attention from policy makers and health institutions who care for pregnant women and babies ${ }^{1}$. The
World Health Organization (WHO) recognizes that oral health is related to the systemic health of the pregnant woman and the fetus, highlighting the importance of the oral health 
approach as a gestational health problem ${ }^{2}$.

Studies suggest that the women may be more susceptible to the development of periodontal diseases during pregnancy ${ }^{3,4}$. A systematic review found that an increase in gingival inflammation during pregnancy can occur even without a significant increase in dental plaque levels ${ }^{5}$. This may be related to the hormonal variations present in pregnancy, since high plasma concentrations of estrogen and progesterone can contribute to trigger or exacerbate preexisting gingival inflammation ${ }^{6}$.

Periodontal bacterial infection and the cascade of events resulting from the action of immuno-inflammatory mediators may be involved in the adverse outcome of pregnancy $^{7-9}$. A systematic review showed that there is consistent evidence that pregnant women with periodontitis are more likely to develop pre-eclampsia and have a premature baby with low birth weight, highlighting periodontal diseases as a relevant risk factor for several adverse pregnancy outcomes ${ }^{10}$. The relationship of sociodemographic profile with periodontal condition during pregnancy was also investigated. The low socioeconomic level has been related to increased bleeding index scores and probing depth in pregnant women ${ }^{11}$.

However, some gaps persist in the relationship between sociodemographic conditions, such as income inequality, and oral health status, so that low income is less likely to affect all oral health outcomes to the same degree $^{12}$.

Although knowledge about complications associated to periodontal diseases in pregnant women has been the focus of the study in several studies, there are still few studies conducted in high risk pregnant women. Gestational risk factors are characteristics, situations or pathologies that lead to a higher probability of complications and, consequently, a greater risk of the woman and/or the fetus to evolve to death. In Brazil, approximately $15 \%$ of pregnancies are characterized as high-risk pregnancy, and the diagnoses of gestational diabetes and arterial hypertension are the most frequent causes of this condition ${ }^{13}$. Considering that oral health cannot be dissociated from systemic health, and that high-risk pregnant women represent a group of higher vulnerability to the development of health complications, this study aimed to investigate the prevalence of periodontal pockets in high-risk pregnant women and to analyze the relationship with sociodemographic factors, medical history, and behavioral profile.

\section{MATERIAL AND METHOD}

This is an observational cross-sectional study performed with high-risk pregnant women from a Brazilian referral center for specialized health care in 2018. The study was approved by Research Ethics Committee on Human Beings (Process Number: 60855316.8.0000.5420) and performed in accordance with the ethical standards as laid down in the 2008 Declaration of Helsinki. Informed consent was signed by all individuals who participated in the study. The study included all high-risk pregnant women who agreed to participate in the survey, regardless of gestational period, skin color and age. Patients with conditions that prevented oral clinical examination were excluded. The classification as high-risk pregnant woman was based on the protocol of the Brazilian Ministry of Health, which evaluates individual characteristics and unfavorable sociodemographic conditions, reproductive history prior the current gestation, presence of chronic morbidities and obstetric illness in the current pregnancy ${ }^{13}$. The sample size was calculated considering a prevalence of $50 \%$, a margin of error of $5 \%$ and a confidence level of $95 \%$, resulting in a minimum sample of 322 high-risk pregnant women.

Previously, a pilot study was conducted with 160 pregnant women not included in the research to make adjustments to the collection instrument and to guarantee the reliability of the data obtained.

The following data were obtained by using a structured questionnaire: age, living area, skin color, marital status, schooling, family income, gestational period, number of children, medical history, diabetes, hypertension, smoking and alcoholism and reason for high-risk pregnancy. The periodontal condition was evaluated by means of the Community Periodontal Index using a flat mouth mirror and millimeter periodontal probe, according to World Health Organization guidelines ${ }^{14}$. In this study, Community Periodontal Index scores 3 and 4 were considered as presence of periodontal pocket. Two examiners were trained and calibrated prior the periodontal condition examination. The intra-examiner and interexaminer kappa concordance were 0.90 and 0.80 , respectively.

Absolute and percentage frequency distributions were used to present the results. Chi-square test was performed to verify the association between periodontal pocket and variables age group, living area, skin color, housing, marital status, schooling, family income, gestational period, number of children, 
arterial hypertension, gestational arterial hypertension, diabetes mellitus, gestational diabetes mellitus, smoking habit and alcoholism.

The multivariate analysis was performed only with the variables that showed $p<0.10$ in the univariate analysis. The relationship of the sociodemographic factors, medical history, and behavioral profile in high-risk pregnant women and periodontal pocket development was evaluated by using multivariate logistic regression analysis to estimate odds ratio (OR) and $95 \%$ confidence interval $(\mathrm{Cl})$. The significance level adopted was 5\%. Statistical analysis was performed using software SPSS Statistics.

RESULTS

Eight hundred patients accepted to participate in the study. The prevalence of periodontal pocket was $27 \%(n=216)$. Table 1 shows data about the sociodemographic factors, medical history, and behavioral profile of the high-risk pregnant women.

Table 1. Presence of periodontal pocket according to sociodemographic characteristics, medical history and behavioral factors of high-risk pregnant women. Araçatuba, Brazil, 2018.

\begin{tabular}{|c|c|c|c|c|c|c|}
\hline \multirow{3}{*}{ Variables } & \multicolumn{3}{|c|}{ Periodontal pocket } & \multicolumn{3}{|c|}{ Total } \\
\hline & \multicolumn{3}{|c|}{ No } & \multicolumn{3}{|c|}{ Yes } \\
\hline & $\mathbf{n}$ & $\%$ & $\mathbf{n}$ & $\%$ & $\mathbf{n}$ & $\%$ \\
\hline \multicolumn{7}{|l|}{ Age group } \\
\hline $13-19$ years & 122 & 20.89 & 27 & 12.50 & 149 & 18.63 \\
\hline $20-34$ years & 358 & 61.30 & 129 & 59.72 & 487 & 60.88 \\
\hline $35-45$ years & 104 & 17.81 & 60 & 27.78 & 164 & 20.50 \\
\hline \multicolumn{7}{|l|}{ Living area } \\
\hline Rural & 17 & 2.91 & 9 & 4.17 & 26 & 3.25 \\
\hline Urban & 567 & 97.09 & 207 & 95.83 & 774 & 96.75 \\
\hline \multicolumn{7}{|l|}{ Skin color } \\
\hline White & 286 & 48.97 & 95 & 43.98 & 381 & 47.63 \\
\hline Non-white & 298 & 51.03 & 121 & 56.02 & 419 & 52.38 \\
\hline \multicolumn{7}{|l|}{ Housing } \\
\hline Own & 207 & 35.45 & 72 & 33.33 & 279 & 34.88 \\
\hline Not own & 377 & 64.55 & 144 & 66.67 & 521 & 65.13 \\
\hline \multicolumn{7}{|l|}{ Marital status } \\
\hline Single/Divorced /Widowed & 160 & 27.40 & 42 & 19.44 & 202 & 25.25 \\
\hline Married & 424 & 72.60 & 174 & 80.56 & 598 & 74.75 \\
\hline \multicolumn{7}{|l|}{ Schooling } \\
\hline$\leq 7$ years & 106 & 18.15 & 56 & 25.93 & 162 & 20.25 \\
\hline $8-10$ years & 185 & 31.68 & 70 & 32.41 & 255 & 31.88 \\
\hline$\geq 11$ years & 293 & 50.17 & 90 & 41.67 & 383 & 47.88 \\
\hline \multicolumn{7}{|l|}{ Monthly family income } \\
\hline$\leq \mathrm{USD} \$ 400.00$ & 249 & $45 \cdot 52$ & 114 & 54.29 & 363 & 47.95 \\
\hline$\geq$ USD $\$ 400.00$ & 298 & 54.48 & 96 & 45.71 & 394 & 52.05 \\
\hline \multicolumn{7}{|l|}{ Gestational period } \\
\hline First Trimester & 100 & 17.12 & 27 & 12.50 & 127 & 15.88 \\
\hline Second Trimester & 277 & 47.43 & 106 & 49.07 & 383 & 47.88 \\
\hline Third Trimester & 207 & 35.45 & 83 & 38.43 & 290 & 36.25 \\
\hline \multicolumn{7}{|l|}{ Number of children } \\
\hline No children & 241 & 41.27 & 70 & 32.41 & 311 & 38.88 \\
\hline One child & 199 & 34.08 & 64 & 29.63 & 263 & 32.88 \\
\hline Two children & 79 & 13.53 & 46 & 21.30 & 125 & 15.63 \\
\hline Three or more children & 65 & 11.13 & 36 & 16.67 & 101 & 12.63 \\
\hline \multicolumn{7}{|l|}{ Arterial hypertension } \\
\hline Yes & 145 & 24.83 & 65 & 30.09 & 210 & 26.25 \\
\hline Not & 439 & 75.17 & 151 & 69.91 & 590 & 73.75 \\
\hline \multicolumn{7}{|c|}{ Gestational arterial hypertension } \\
\hline Yes & 76 & 52.41 & 32 & 49.23 & 108 & 51.43 \\
\hline Not & 69 & 47.59 & 33 & 50.77 & 102 & 48.57 \\
\hline \multicolumn{7}{|l|}{ Diabetes Mellitus } \\
\hline Yes & 42 & 7.19 & 36 & 16.67 & 78 & 9.75 \\
\hline Not & 542 & 92.81 & 180 & 83.33 & 722 & 90.25 \\
\hline Gestational Diabetes Me & llitus & & & & & \\
\hline Yes & 19 & 45.24 & 17 & 47.22 & 36 & 46.15 \\
\hline Not & 23 & 54.76 & 19 & 52.78 & 42 & 53.85 \\
\hline Smoking & & & & & & \\
\hline Yes & 77 & 13.18 & 58 & 26.85 & 135 & 16.88 \\
\hline Not & 507 & 86.82 & 158 & 73.15 & 665 & 83.13 \\
\hline Alcoholism & & & & & & \\
\hline Yes & 34 & 5.82 & 21 & 9.72 & 55 & 6.88 \\
\hline Not & 550 & 94.18 & 195 & 90.28 & 745 & 93.13 \\
\hline Reasons for High Risk $P$ & regnan & & & & & \\
\hline Personal characteristics & 127 & 21.75 & 39 & 18.06 & 166 & 20.75 \\
\hline Obstetric history & 54 & 9.25 & 15 & 6.94 & 69 & 8.63 \\
\hline Chronic morbidities & 217 & 37.16 & 100 & 46.30 & 317 & 39.63 \\
\hline Current obstetric changes & 186 & 31.85 & 62 & 28.70 & 248 & 31.00 \\
\hline
\end{tabular}

The mean age of the patients was 27.4 years, and the majority were in the 20 to 34 age group. More than $95 \%$ of the pregnant women lived in urban areas and approximately half of them were non-white. About one-fifth of the participants had up to 7 years of schooling and approximately half of them had a monthly family income of less than USD $\$ 400.00$ and was in the second trimester of the pregnancy. More than a quarter of the patients had hypertension and about $10 \%$ had diabetes mellitus. Smoking and alcoholism were observed in 17\% and $7 \%$ of pregnant women, respectively. More than a quarter of patients had more than one child and the main reasons for high-risk pregnancy were chronic morbidities and current obstetric changes. The univariate logistic regression analysis showed that the variables age group ( $p$ $=0.001)$, marital status $(p=0.022)$, schooling $(p$ $=0.030)$, family income $(p=0.031)$, number of children ( $p=0.003)$, diabetes mellitus $(p=$ $0.000)$ and smoking $(p=0.000)$ were associated with periodontal pocket (Table 2).

Table 2. Univariate logistic regression analysis for periodontal pocket in high-risk pregnant women. Araçatuba, Brazil, 2018.

\begin{tabular}{|c|c|c|c|}
\hline \multirow[b]{2}{*}{ Variables } & \multicolumn{3}{|c|}{ Univariate Analysis } \\
\hline & p-Value & $\begin{array}{l}\text { Odds } \\
\text { Ratio }\end{array}$ & $\begin{array}{c}\text { 95\% Confidence } \\
\text { Interval }\end{array}$ \\
\hline Age group & 0.001 & & \\
\hline $13-19$ years & - & - & - \\
\hline $20-34$ years & 0.039 & 1.628 & $1.025-2.587$ \\
\hline $35-45$ years & 0.000 & 2.607 & $1.543-4.403$ \\
\hline \multicolumn{4}{|l|}{ Living area } \\
\hline Rural & 0.376 & 1.450 & $0.636-3 \cdot 304$ \\
\hline Urban & - & - & $\frac{-3.004}{30}$ \\
\hline \multicolumn{4}{|l|}{ Skin color } \\
\hline White & - & - & - \\
\hline Non-white & 0.210 & 1.222 & $0.893-1.673$ \\
\hline \multicolumn{4}{|l|}{ Housing } \\
\hline Own & - & - & - \\
\hline Not own & 0.578 & 1.098 & $0.790-1.527$ \\
\hline \multicolumn{4}{|l|}{ Marital status } \\
\hline \multicolumn{4}{|l|}{ Single/Divorced /Widowed } \\
\hline Married & 0.022 & 1.563 & $1.066-2.293$ \\
\hline Schooling & 0.030 & & \\
\hline$\leq 7$ years & 0.008 & 1.720 & $1.152-2.568$ \\
\hline $8-10$ years & 0.260 & 1.232 & $0.857-1.770$ \\
\hline$\geq 11$ years & - & - & - \\
\hline \multicolumn{4}{|l|}{ Monthly family income } \\
\hline$\leq$ USD $\$ 400.00$ & 0.031 & 1.421 & $1.033-1.956$ \\
\hline$\geq$ USD $\$ 400.00$ & - & - & -2 \\
\hline Gestational period & 0.276 & & \\
\hline First Trimester & - & - & - \\
\hline Second Trimester & 0.155 & 1.417 & $0.877-2.291$ \\
\hline Third Trimester & 0.118 & 1.485 & $0.905-2.437$ \\
\hline Number of children & 0.003 & & \\
\hline No children & - & - & - \\
\hline One child & 0.606 & 1.107 & $0.752-1.631$ \\
\hline Two children & 0.002 & 2.005 & $1.278-3.146$ \\
\hline Three or more children & 0.009 & $\begin{array}{l}2.005 \\
1.907\end{array}$ & $1.172-3.101$ \\
\hline \multicolumn{4}{|l|}{ Arterial hypertension } \\
\hline Yes & 0.134 & 1.303 & $0.922-1.842$ \\
\hline Not & - & - & - \\
\hline \multicolumn{4}{|l|}{ Gestational arterial hypertension } \\
\hline Yes & 0.670 & 0.880 & $0.490-1.581$ \\
\hline Not & - & - & - \\
\hline \multicolumn{4}{|l|}{ Diabetes Mellitus } \\
\hline Yes & 0.000 & 2.581 & $1.603-4.154$ \\
\hline Not & - & - & - \\
\hline \multicolumn{4}{|l|}{ Gestational Diabetes Mellitus } \\
\hline Yes & 0.861 & 1.083 & $0.443-2.645$ \\
\hline Not & - & - & - \\
\hline \multicolumn{4}{|l|}{ Smoking } \\
\hline Yes & 0.000 & 2.417 & $1.645-3.551$ \\
\hline Not & - & - & - \\
\hline \multicolumn{4}{|l|}{ Alcoholism } \\
\hline Yes & 0.055 & 1.742 & $0.987-3.074$ \\
\hline Not & - & - & - \\
\hline Reasons for High Risk Pregnancy & 0.122 & & \\
\hline Personal characteristics & - & - & - \\
\hline Obstetric history & 0.771 & 0.905 & $0.460-1.777$ \\
\hline Chronic morbidities & 0.064 & 1.501 & $0.976-2.307$ \\
\hline Current obstetric changes & 0.727 & 1.085 & $0.685-1.719$ \\
\hline
\end{tabular}


The multivariate logistic regression analysis showed that the variables age group $(\mathrm{OR}=2.498,95 \% \mathrm{Cl}=1.297-4.813, \mathrm{p}=0.006)$, schooling $(\mathrm{OR}=1.638,95 \% \mathrm{Cl}=1.017-2.638, \mathrm{p}$ $=0.042)$, family income $(\mathrm{OR}=1.431,95 \% \mathrm{Cl}=$ 1.004-2.041, $\mathrm{p}=0.048)$, diabetes mellitus (OR = $2.508,95 \% \mathrm{Cl}=1.511-4.163, \mathrm{p}=0.000)$ and smoking $(\mathrm{OR}=2.211,95 \% \mathrm{Cl}=1.460-3.348 ; p$ $=0.000$ ) remained significantly associated with periodontal pocket (Table 3).

Table 3. Multivariate logistic regression analysis for periodontal pocket in high-risk pregnant women. Araçatuba, Brazil, 2018.

\begin{tabular}{|c|c|c|c|}
\hline \multirow[b]{2}{*}{ Variables } & \multicolumn{3}{|c|}{ Multivariate Analysis } \\
\hline & p-Value & $\begin{array}{l}\text { Odds } \\
\text { Ratio }\end{array}$ & $\begin{array}{c}\text { 95\% Confidence } \\
\text { Interval }\end{array}$ \\
\hline \multicolumn{4}{|l|}{ Age group } \\
\hline $13-19$ years & - & - & - \\
\hline $20-34$ years & 0.091 & 1.625 & $0.925-2.852$ \\
\hline $35-45$ years & 0.006 & 2.498 & $1.297-4.813$ \\
\hline \multicolumn{4}{|l|}{ Marital status } \\
\hline \multicolumn{4}{|c|}{ Single/Divorced /Widowed } \\
\hline Married & 0.174 & 1.343 & $0.878-2.054$ \\
\hline \multicolumn{4}{|l|}{ Schooling } \\
\hline$\leq 7$ years & 0.042 & 1.638 & $1.017-2.638$ \\
\hline $8-10$ years & 0.097 & 1.423 & $0.939-2.156$ \\
\hline$\geq 11$ years & - & - & - \\
\hline \multicolumn{4}{|c|}{ Monthly family income } \\
\hline$\leq \mathrm{USD} \$ 400.00$ & 0.048 & 1.431 & $1.004-2.041$ \\
\hline$\geq$ USD $\$ 400.00$ & - & - & - \\
\hline \multicolumn{4}{|l|}{ Number of children } \\
\hline No children & - & - & - \\
\hline One child & 0.280 & 0.786 & $0.509-1.216$ \\
\hline Two children & 0.808 & 1,068 & $0.629-1.815$ \\
\hline Three or more children & 0.321 & 0.737 & $0.403-1.347$ \\
\hline \multicolumn{4}{|l|}{ Diabetes Mellitus } \\
\hline Yes & 0.000 & 2.508 & $1.511-4.163$ \\
\hline Not & - & - & - \\
\hline \multicolumn{4}{|l|}{ Smoking } \\
\hline Yes & 0.000 & 2.211 & $1.460-3 \cdot 348$ \\
\hline Not & - & - & - \\
\hline
\end{tabular}

\section{DISCUSSION}

Periodontal pocket was observed in more than a quarter of the high-risk pregnant women and its occurrence was associated with advanced age, low schooling, low family income, diabetes and smoking.

Periodontal tissue changes may be influenced by the immunological status and hormonal variations of the pregnant woman.6 Additionally, gestational development under conditions of stress and anxiety may lead the pregnant woman to neglect her oral hygiene, contributing to the deterioration of the periodontal condition. However, it should be emphasized that pregnancy itself is not a risk factor for periodontal diseases, so maintaining adequate levels of oral hygiene during gestation is essential for the prevention of periodontitis ${ }^{15}$.

Periodontal diseases can negatively affect the quality of life of individuals, involving aspects such as pain and functional and aesthetic impairment ${ }^{16,17}$. This relationship becomes even more relevant when considering the situation of greater vulnerability and health risk in the high-risk pregnant woman.

Our results are in accordance to scientific evidence showing that the occurrence and severity of periodontal diseases increases with age $^{18,19}$. A systematic review has shown that a strong increase in the prevalence of periodontal disease has been observed in individuals between 30 and 40 years of age, stabilizing at advanced age ${ }^{19}$. The influence of age on the occurrence of periodontal disease can be understood by successive exposure to proinflammatory conditions throughout life, dysregulation of the immune system and alterations in the ability of cells and tissues to heal $^{18}$.

In this study, the low family income and low schooling were significantly associated with the presence of periodontal pocket. Our findings are in agreement with studies that observed association between low individual/family income and adverse oral health outcomes, including a positive association between income inequality and periodontal disease ${ }^{12,20}$. A study performed to evaluate the periodontal condition of 130 pregnant women verified that gingivitis due to plaque accumulation was the most frequent periodontal condition and was significantly related to professional level, schooling and previous periodontal maintenance, highlighting the importance of adopting periodontal preventive measures for pregnant women ${ }^{21}$. Pregnant women with higher education level are more likely to have an adequate level of knowledge about oral health, however, there is a need to reinforce some aspects related to oral hygiene, especially preventive methods and myths about dental treatment during pregnancy ${ }^{22}$. Taken together, the data suggest that the development of oral health promotion strategies and actions during prenatal care should consider the sociodemographic aspects of pregnant women.

The data revealed a significant association between smoking and periodontal pocket in the high-risk pregnant women. Comparing the results of a recent systematic review, it is noted that the prevalence of smoking observed in the present study $(17 \%)$ is above the overall prevalence of smoking during pregnancy. Estimates indicate that the prevalence of smoking in pregnant women is $8.1 \%$ in Europe, $5.9 \%$ in America, $1.2 \%$ in Southeast Asia, $1.2 \%$ in the Western Pacific, $0.9 \%$ in the Eastern Mediterranean and $0.8 \%$ in Africa $^{23}$. Evidence has shown that smokers have greater susceptibility, severity and rate of progression of periodontal diseases compared to nonsmokers. In addition, smokers have greater tooth loss and have a less favorable response to periodontal therapy than nonsmokers ${ }^{24}$. This may be related to the fact that smoking reduces the effectiveness of the immune response against periodontal pathogens in patients with periodontitis ${ }^{25}$. 
Moreover, a study showed that smokers had a subgingival microbial profile with high pathogen diversity and poor in commensals, suggesting that smoking may develop a risky environment for the development of periodontal diseases ${ }^{26}$.

It was observed a significant association between diabetes mellitus and periodontal pocket. The relationship between systemic diseases and hormonal alterations, especially diabetes, has been reported as an important factor in the development of periodontal disease during pregnancy ${ }^{27,28}$. There is a bidirectional relationship between diabetes mellitus and periodontal diseases, so that diabetes increases the risk and severity of periodontitis while it can worsen insulin sensitivity and impair glycemic control $^{29,30}$. The mechanisms involved in the relationship between these two diseases are not completely elucidated, but it is suggested that aspects of the immune system, neutrophil activity and inflammatory cytokines are involved ${ }^{31}$.

Study showed that periodontal therapy can improve glycemic control in type 2 diabetics, emphasizing that periodontal health control is not only important for oral health, but also for systemic health ${ }^{32}$. Additionally, evidence suggest the consequences of diabetes during pregnancy involve increased rates of congenital malformations and perinatal mortality, representing important implications for public health ${ }^{33}$.

The study design can be considered a limitation of the present research, since in a cross-sectional study the exposure factors and the results are evaluated concomitantly and, therefore, it is not possible to establish a temporal sequence between the exposure and the result.

Lack of oral health care during gestation may have negative outcomes for high-risk pregnant women, as suggested by studies that indicate an association between poor oral health status and poorer quality of life during pregnancy ${ }^{34}$. Strategies and actions aimed at maintaining the oral health of high-risk pregnant women should be developed and prioritized, especially for low-income populations.

CONCLUSION

The prevalence of periodontal pocket was high and the factors age, low schooling, low family income, diabetes and smoking habit are related to greater chances of occurrence of the disease in high-risk pregnant women. It is essential to ensure the prevention, promotion and recovery of the oral health of pregnant women during prenatal care, especially in high- risk pregnancies, in order to minimize undesirable perinatal results and improve the quality of life and well-being of the pregnant woman and the child.

ACKNOWLEDGEMENTS

This study was financed in part by the Coordenação de Aperfeiçoamento de Pessoal de Nível Superior - Brasil (CAPES) - Finance Code 001.

\section{REFERENCES}

1. Morgan MA, Crall J, Goldenberg RL, Schulkin $\mathrm{J}$. Oral health during pregnancy. J Matern Fetal Neonatal Med. 2009;22:733-39.

2. Petersen PE. World Health Organization global policy for improvement of oral health - World Health Assembly 2007. Int Dent J. 2008;58:115-21.

3. Gil L, Mínguez I, Caffesse R, Llambés F. Periodontal disease in pregnancy: The influence of general factors and inflammatory mediators. Oral Health Prev Dent. 2019;17: 69-73.

4. Rakchanok N, Amporn D, Yoshida Y, Harun-OrRashid M, Sakamoto J. Dental caries and gingivitis among pregnant and non-pregnant women in Chiang Mai, Thailand. Nagoya J Med Sci. 2010;72:43-50.

5. Figuero E, Carrillo-De-Albornoz A, Martín C, Tobías A, Herrera D. Effect of pregnancy on gingival inflammation in systemically healthy women: a systematic review. J Clin Periodontol. 2013;40:457-63.

6. Wu M, Chen SW, Jiang SY. Relationship between gingival inflammation and pregnancy. Mediators Inflamm. 2015;2015:623427.

7. Corona MLM, Valdez ATG, Loyola APP, Zarazúa RI, Bermeo NLR, López BSG, Solís CEM. Preterm birth associated with periodontal and dental indicators: a pilot case-control study in a developing country. J Matern Fetal Neonatal Med. 2021;34:690-95.

8. Lafaurie GI, Gómez LA, Montenegro DA, Avila J, Tamayo MC, Lancheros MC, Quiceno J, Trujillo TG, Noriega LA, Grueso ML, Cepeda K. Periodontal condition is associated with adverse perinatal outcomes and premature rupture of membranes in low-income pregnant women in Bogota, Colombia: a case-control study. J Matern Fetal Neonatal Med. 2020;33:16-23.

9. Usin MM, Menso J, Rodríguez VI, González A, Tabares S, Parodi R, Sembaj A. Association between maternal periodontitis and preterm and/or low birth weight infants in normal pregnancies. J Matern Fetal Neonatal Med. 2016;29:115-19.

10. Daalderop LA, Wieland BV, Tomsin K, Reyes L, Kramer BW, Vanterpool SF, Been JV. Periodontal disease and pregnancy outcomes: 
overview of systematic reviews. JDR Clin Trans Res. 2018;3:10-27.

11. Dhaliwal JS, Leh G, Sodhi SK, Sachdeva S. Evaluation of socio-demographic variables affecting the periodontal health of pregnant women in Chandigarh, India. J Indian Soc Periodontol. 2013;17:52-7.

12. Singh A, Peres MA, Watt RG. The relationship between income and oral health: a critical review. J Dent Res. 2019;98:853-60.

13. Brazil. High risk pregnancy: technical manual. 5th ed. Brasilia: Brazilian Ministry of Health; 2012.

14. World Health Organization. Oral health surveys: basic methods. 5th ed. Geneva: World Health Organization; 2013.

15. González-Jaranay M, Téllez L, Roa-López A, Moreno GG, Moreu G. Periodontal status during pregnancy and postpartum. PLoS One. 2017;12:e0178234.

16. Ferreira MC, Dias-Pereira AC, Branco-deAlmeida LS, Martins CC, Paiva SM. Impact of periodontal disease on quality of life: a systematic review. J Periodontal Res. 2017; 52:651-65.

17. Musskopf ML, Milanesi FC, Rocha JM, Fiorini $\mathrm{T}$, Moreira $\mathrm{CHC}$, Susin $\mathrm{C}$ et al. Oral health related quality of life among pregnant women: a randomized controlled trial. Braz Oral Res. 2018;32:e002.

18. López R, Smith PC, Göstemeyer G, Schwendicke F. Ageing, dental caries and periodontal diseases. J Clin Periodontol. 2017;44:S145-S52.

19. Kassebaum NJ, Bernabé E, Dahiya M, Bhandari B, Murray CJL, Marcenes W. Global burden of severe periodontitis in 1990-2010: a systematic review and meta-regression. J Dent Res. 2014;93:1045-53.

20. Vettore MV, Aqeeli A. The roles of contextual and individual social determinants of oral health-related quality of life in Brazilian adults. Qual Life Res. 2016;25:1029-42.

21. Machuca G, Khoshfeiz O, Lacalle JR, Machuca $C$, Bullón $P$. The influence of general health and socio-cultural variables on the periodontal condition of pregnant women. J Periodontol. 1999;70:779-85.

22. Thomas NJ, Middleton PF, Crowther CA. Oral and dental health care practices in pregnant women in Australia: a postnatal survey. BMC Pregnancy Childbirth. 2008;8:13.

23. Lange S, Probst C, Rehm J, Popova S. National, regional, and global prevalence of smoking during pregnancy in the general population: a systematic review and metaanalysis. Lancet Glob Health. 2018;6:e769-e76.

24. Nociti FH, Casati MZ, Duarte PM. Current perspective of the impact of smoking on the progression and treatment of periodontitis. Periodontol 2000. 2015;67:187-210.
25. Tebloeva LM, Revazova ZE, Fabrikant KG, Dmitrieva LA, Gurevich KG. Differences in immune response to Porphyromonas gingivalis. J Contemp Dent Pract. 2014;15:573-5.

26. Mason MR, Preshaw PM, Nagaraja $H N$, Dabdoub SM, Rahman A, Kumar PS. The subgingival microbiome of clinically healthy current and never smokers. ISME $J$. 2015;9:268-72.

27. Abariga SA, Whitcomb BW. Periodontitis and gestational diabetes mellitus: a systematic review and meta-analysis of observational studies. BMC Pregnancy Childbirth. 2016; 16:344.

28. Kumar A, Sharma DS, Verma M, Lamba AK, Gupta MM, Sharma S, Perumal V. Association between periodontal disease and gestational diabetes mellitus-A prospective cohort study. J Clin Periodontol. 2018;45:920-31.

29. Chee B, Park B, Bartold PM. Periodontitis and type II diabetes: a two-way relationship. Int J Evid Based Health. 2013;11:317-29.

30. Badiger AB, Gowda TM, Chandra K, Mehta DS. Bilateral interrelationship of diabetes and periodontium. Curr Diabetes Rev. 2019;15: 357-62.

31. Preshaw PM, Alba AL, Herrera D, Jepsen S, Konstantinidis A, Makrilakis K, Taylor R. Periodontitis and diabetes: a two-way relationship. Diabetologia. 2012;55:21-31.

32. Stanko P, Izakovicova Holla L. Bidirectional association between diabetes mellitus and inflammatory periodontal disease. A review. Biomed Pap Med Fac Univ Palacky Olomouc Czech Repub. 2014;158:35-38.

33. McCance DR. Diabetes in pregnancy. Best Pract Res Clin Obstet Gynaecol. 2015;29: 685-99.

34. Moimaz SA, Rocha NB, Garbin AJ, Garbin CAS, Saliba O. Influence of oral health on quality of life in pregnant women. Acta Odontol Latinoam. 2016;29:186-93.

\section{CONFLICTS OF INTERESTS}

The authors declare no conflicts of interests.

\section{CORRESPONDING AUTHOR}

\section{Fernando Yamamoto Chiba}

Department of Preventive and Restorative Dentistry, São Paulo State University (UNESP),

School of Dentistry,

16015-050 Araçatuba - SP, Brazil

E-mail: fernando.chiba@unesp.br 